\title{
KAJIAN UJARAN KEBENCIAN DI MEDIA SOSIAL
}

\author{
Dian Junita Ningrum, Suryadi, dan Dian Eka Chandra Wardhana \\ Program Studi Pendidikan Bahasa Indonesia \\ Jurusan Pendidikan Bahasa dan Seni \\ FKIP Universitas Bengkulu \\ dianjunitaningrum@gmail.com
}

\begin{abstract}
Abstrak
Ujaran kebencian merupakan fenomena kebahasaan yang bertolak belakang dengan konsep kesantunan berbahasa sebagai indikator kecerdasan linguistik dan etika berkomunikasi. Tujuan penelitian ini untuk mendeskripsikan bentuk tindak ujaran kebencian di media sosial serta jenis tindak tutur ilokusi pada komentar netizen di facebook. Metode dalam penelitian ini adalah deskriptif. Data berupa tuturan netizen pada kolom komentar yang mengandung ujaran kebencian dan tindak tutur ilokusi asertif, direktif, komisif, ekspresif dan deklaratif. Teknik pengumpulan datanya adalah dokumentasi. Langkah analisis data dalam penelitian ini menggunakan analisis kualitatif deskriptif. Hasil penelitian ini menunjukkan bentuk ujaran kebencian yang ditemukan antara lain bentuk penghinaan, menghasut, provokasi politik, pencemaran nama baik, penistaan agama, dan menyebarkan berita bohong (hoax) yang tergolong menjadi empat topik yaitu tentang masalah politik, sosial, ekonomi dan agama. Adapun jenis tindak tutur ilokusi yang ditemukan antara lain bentuk tindak tutur ilokusi asertif $32,63 \%$, direktif $20,63 \%$, komisif 9,26\%, ekspresif 35,9\%, dan deklaratif 1,58\% dengan total keseluruhan 882 data tuturan dari 20 konteks tuturan. Kesimpulan pertama, pada konteks tuturan paling banyak ditemukan bentuk ujaran kebencian penistaan agama dan pada kolom komentar paling banyak ditemukan bentuk penghinaan bersifat mencela. Kedua, jenis Tindak Tutur Ilokusi (TTI) paling banyak ditemukan pada tuturan netizen di kolom komentar adalah TTI Ekspresif kategori mengkritik.
\end{abstract}

Kata kunci : Ujaran Kebencian (hate speech), fungsi tindak tutur ilokusi, komentar facebook (fb) 2018

\begin{abstract}
Hate speech is a linguistic phenomenon that contradicts the concept of politeness of language as an indicator of linguistic intelligence and communication ethics. The purpose of this study is to describe the form of hate speech on social media and the types of illocutionary act on netizen comments on Facebook. The method in this study is descriptive. The data is a netizen utterance in the comments column containing hate speech and types of illocutionary act assertive, directive, commissive, expressive and declarative. The data collection technique is documentation. The step of data analysis in this study uses descriptive qualitative analysis. The results of this study indicate the form of hate speech found in the form of insult, incite, political provocation, defamation, desecration religious, and spreading hoaxes which are classified into four
\end{abstract}


topics, problem on political, social, economic and religious issues. The types of illocutionary speech acts found were ilocutionary acts of assertive $32.63 \%$, directive $20.63 \%$, commissive $9.26 \%$, expressive $35.9 \%$, and declarative $1.58 \%$ with a total of 882 speech data from 20 the speech context. The first conclusion, in the speech context most widely found hate speech of religious desecration and in the comments column, most widely found form insult of reproachful. Second, the type of llocutionary Speech Act (TTI) is most widely found in the netizens speech in the comments column is the TTI Expressive of Criticizing Category 12.69\%.

\section{Keywords: Hate Speech, Illocutionary Speech Acts, Facebook Comments (Fb) 2018}

\section{PENDAHULUAN}

Media sosial (selanjutnya disingkat "medsos") saat ini telah menjadi bagian dari kehidupan masyarakat Indonesia yang sangat fenomenal. Berbagai macam keunggulan dan kemudahan ditawarkan untuk melakukan interaksi kepada semua orang baik dalam hal bisnis sekalipun dari berbagai kalangan. Tidak hanya itu, dengan adanya perkembangan penggunaan internet serta perangkat teknologi komunikasi seperti smartphone yang semakin maju, menjadi salah satu pendorong pertumbuhan situs-situs jejaring baru yang menawarkan pertemanan dan informasi secara online. Medsos juga telah menjadi backbone (tulang punggung) sebagai sarana komunikasi abad digital ini (Kemendag, 2014:43).

Tingginya pengguna konten medsos memudahkan orang untuk berkomunikasi. Komunikasi adalah proses penyampaian pikiran atau perasaan oleh seseorang kepada orang lain dengan menggunakan lambang-lambang yang bermakna bagi kedua pihak, dalam situasi yang tertentu, menggunakan media tertentu untuk merubah sikap atau tingkah laku seorang atau sejumlah orang sehingga menimbulkan efek tertentu yang di harapkan (Effendy, 2003:13).
Pada hakikatnya, setiap orang bebas berkomunikasi dan prosesnya berlangsung dalam berbagai konteks baik fisik, psikologis, maupun sosial, karena proses komunikasi tidak terjadi pada sebuah ruang kosong. Oleh karena itu, komunikasi sebagai sarana kehidupan memiliki beberapa fungsi yaitu sebagai alat kendali, motivasi, informasi serta sebagai sarana pengungkapan emosional (Robbins, 2002:310-311).

Salah satu sarana komunikasi pada media sosial ini berlangsung secara publik. Sifat opennes of media atau keterbukaan informasi di media sosial inilah yang menjadi pemicu tingginya kecenderungan masyarakat untuk melakukan ujaran kebencian, seperti ketersediaan fasilitas komentar untuk pembaca pada media yang berbasis elektronik. Hal itu menyebabkan hubungan antara penulis dan pembaca menjadi resiprokal, bisa, dan mudah untuk saling mengomentari.

Beragam faktor untuk beragam problematik. Interaksi antarpribadi menjadi tidak terkontrol, karena bentuk-bentuk tindak ujaran kebencian itu saling menstimulus satu dengan lainnya. Jika terus berlanjut, efeknya akan mempengaruhi seseorang dalam waktu yang pendek hingga waktu yang lama.

Indikasi kecerdasan linguistik perlu diperhatikan lebih lanjut dan menjadi 
sorotan ilmu kebahasaan terutama dalam hal berbahasa Indonesia yang baik dan benar dalam berinteraksi dan berkomunikasi antar sesama. Mengucapkan kata apapun tidaklah salah, tetapi menggunakan kata apapun memerlukan telaah. Maka dari itu, kecerdasan linguistik seseorang memperlihatkan kemampuannya dalam mengelola diksi dan emosi sesuai konteks situasi.

Ujaran kebencian ini bertolak belakang dengan konsep kesantunan berbahasa sebagai indikator kecerdasan linguistik, sama halnya dengan etika berkomunikasi. Etika adalah kesadaran dan pengetahuan mengenai baik dan buruk atas perilaku atau tindakan yang dilakukan oleh manusia (Kemendag, 2014:37). Etika bisa terlihat dari cara para netizen (pengguna aktif medsos) bertutur. Tidak adanya filter atau saringan pertimbangan nilai baik dan buruk merupakan awal dari bencana penyalahgunaan medsos di era gadget.

Saat ini banyak kasus ujaran kebencian seperti penghinaan, pencemaran nama baik, penistaan agama, memprovokasi bahkan menyebarkan berita-berita bohong (hoax) di berbagai aplikasi media sosial salah satunya $\mathrm{Fb}$. Hal ini dikarenakan para netizen diberi kebebasan pribadi dalam mengeksplor medsos tersebut sehingga mereka bebas berujar di medsos tanpa berpikir akibat yang terjadi setelahnya apalagi rasa benci merupakan sifat alamiah manusia.

Dengan demikian, tindak ujar (speech act) berfungsi sebagai sarana penindak maksud penutur dalam tuturan. Semua kalimat ujaran yang diucapkan oleh penutur sebenarnya mengandung fungsi komunikasi tertentu. Tuturan dari penutur (selanjutnya disebut $\mathrm{Pn}$ ) tentu saja tidak semata-mata hanya asal bicara, tetapi mengandung maksud tertentu (Mulyana, 2010:80). Sehingga tindak tutur dengan ujaran kebencian yang dikaji dalam penelitian ini merupakan bagian dari peristiwa tindak tutur.

Teori tindak tutur merupakan teori yang memusatkan perhatian pada cara penggunaan bahasa dalam mengkomunikasikan maksud dan tujuan Pn dan maksud penggunaan bahasa yang dilaksanakannya. Berkenaan dengan tuturan tersebut, Searle dalam (Cummings, 2007:9) mengemukakan tiga jenis tindakan yang bisa diwujudkan seorang penutur yaitu, (1) tindak tutur lokusi yang disebut sebagai the act of saying something yang artinya tindak tutur untuk menyatakan sesuatu tanpa keharusan bagi Pn melaksanakan tuturannya., (2) tindak tutur ilokusi yang disebut the act of doing something yaitu tindak tutur yang mengandung maksud dan fungsi untuk melakukan suatu tindakan, (3) tindak tutur perlokusi yang disebut sebagai the act of affecting someone yakni sebuah tuturan yang diutarakan oleh seseorang dimaksudkan untuk memberikan daya pengaruh atau efek bagi yang mendengarnya. Efek atau daya pengaruh ini dapat secara atau tidak disengaja dikreasikan oleh penuturnya.

Hal tersebut menjadi salah satu alasan penulis tertarik melakukan penelitian terhadap fenomena ujaran kebencian di medsos. Terkait dengan bentuk-bentuk ujaran kebencian di medsos dan bagaimana ujaran-ujaran tersebut dapat mempengaruhi orang lain, memprovokasi, menjadi sorotan publik bahkan menimbulkan perpecahan hanya karena sebuah tuturan para netizen tersebut.

Semua bentuk ujaran kebencian yang disebarkan melalui situs jejaring sosial secara sengaja atau tidak sengaja, dapat merugikan diri sendiri dan orang lain. sehingga perlu dirumuskan suatu masalah penelitian bagaimanakah bentuk-bentuk ujaran kebencian di medsos yang dominan masih dilakukan oleh masyarakat berdasarkan (SE/06/X/2015) serta jenis 
tindak tutur ilokusi yang terkandung dalam tuturan tersebut.

\section{METODE PENELITIAN}

Penelitian ini menggunakan rancangan penelitian deskriptif kualitatif dengan pendekatan pragmatik. Metode yang digunakan adalah metode deskriptif. Data dalam penelitian ini berupa tuturan-tuturan netizen pada kolom komentar yang mengandung ujaran kebencian dan fungsi ilokusi asertif, direktif, komisif, ekspresif dan deklaratif. Media sosial yang menjadi sumber adalah Facebook (Fb) selama 2,5 bulan, dari bulan Januari 2018 hingga pertengahan april 2018. Tuturan di $\mathrm{Fb}$ merupakan bentuk bahasa lisan yang dituliskan di kolom komentar maupun status dengan ciri-ciri bahasa lisan tidak harus memperhatikan unsur gramatikal, hanya perlu intonasi dan tergantung situasi, kondisi, ruang dan waktu atau ditunjang oleh situasi pemakaian (Subarianto,2000:12). Tuturan tersebut bisa berbentuk tulis (komentar) dan bisa berbentuk lisan. Jika data tersebut berupa tuturan lisan dalam bentuk video, maka tuturan tersebut akan di transkrip terlebih dahulu baru di analisis. Data ujaran kebencian digolongkan menjadi empat topik yaitu masalah politik, masalah sosial, masalah ekonomi dan masalah agama. Teknik pengumpulan data menggunakan teknik dokumentasi. Langkah-langkah analisis data dalam penelitian : 1) mengumpulkan data, 2) mereduksi data, 3) mengklasifikasikan data, 4) menyajikan data, dan 5) menyimpulkan data.

\section{HASIL PENELITIAN DAN PEMBAHASAN}

Berdasarkan hasil penelitian yang telah dilakukan mengenai bentuk ujaran kebencian yang ada di media sosial diperoleh 18 konteks yang mengandung kebencian dari total 20 konteks tuturan. Konteks ujaran kebencian yang ditemukan tergolong dalam bentuk penghinaan, pencemaran nama baik, memprovokasi, menghasut, penistaan agama dan penyebaran berita bohong (hoax). Sedangkan jumlah tuturan yang mengandung ujaran kebencian diperoleh sebanyak 228 tuturan dari 882 data kategori penghinaan, pencemaran nama baik, perbuatan yang tidak menyenangkan, memprovokasi dan menghasut.

Ujaran kebencian kategori penghinaan diperoleh sebanyak 2 konteks tuturan dari total 20 konteks data dan 149 tuturan $(16,89 \%)$ dari total data keseluruhan yang ditandai dengan empat unsur penting dari pasal 310 ayat (1) yaitu: (1) sengaja, (2) menyerang kehormatan atau nama baik seseorang, (3) menuduhkan suatu hal (memalukan), (4) dengan maksud diketahui umum, maka empat unsur tersebut harus mutlak ada sehingga seseorang dapat dikenakan delik penghinaan. Adapun fungsi dari ujaran kebencian penghinaan ini bertujuan untuk menyerang kehormatan dan nama baik seseorang sehingga pihak yang bersangkutan akan merasa malu dan tuturan ini merupakan bentuk ujaran kebencian yang paling banyak ditemukan dari seluruh komentar netizen di Fb. Ujaran kebencian penghinaan yang ditemukan dari hasil analisis ini berkaitan dengan pejabatpejabat negara seperti mantan presiden sekaligus ketua umum partai PDIP Ibu Megawati Soekarnoputri, Bapak Djan Faridz selaku ketua umum Dewan Pimpinan Pusat Partai Persatuan Pembangunan (DPP PPP), dan Presiden Jokowi.

Ujaran kebencian kategori pencemaran nama baik diperoleh sebanyak 3 konteks tuturan dari total 20 konteks data dan 8 tuturan $(0,90 \%)$ dari total data keseluruhan yang ditandai dengan unsur-unsur antara lain, (1) adanya hal atau sesuatu yang tidak benar yang dikomunikasikan lewat internet (fitnah), (2) hal atau keadaan tersebut mengenai diri seseorang atau suatu badan, (3) hal atau keadaan tersebut dipublikasikan kepada pihak lain, dan (4) 
publikasi tersebut mengakibatkan kerugian bagi seseorang yang menjadi objek pencemaran nama baik. Adapun fungsi dari ujaran kebencian pencemaran nama baik ini bertujuan untuk menjatuhkan nama baik subjek hukum dan badan hukum atau badan usaha agar pihak-pihak yang bersangkutan merasa dirugikan dalam hal moril maupun materil. Ujaran kebencian pencemaran nama baik yang ditemukan dari hasil analisis ini berkaitan dengan subjek hukum seperti Presiden Jokowi, seorang janda yang bernama Nyla Nylala, Warga Batak, partai PDIP dan keluarga mantan Presiden Soekarno dan badan hukum (badan usaha) seperti perusahaan air mineral dan coklat.

Ujaran kebencian kategori memprovokasi diperoleh sebanyak 3 konteks dari total 20 konteks data dan 54 tuturan $(6,12 \%)$ dari total data keseluruhan yang ditandai dengan unsur-unsur antara lain, (1) sengaja, (2) hal atau keadaan tersebut mengenai diri seseorang atau suatu badan, (3) menuduhkan suatu hal, (4) dengan maksud membangkitkan kemarahan dan berpikiran negatif. Adapun kegiatan provokasi yang paling banyak terjadi adalah provokasi politik. Provokasi politik ini bertujuan untuk memanasmanasi lawan politik, menjatuhkan citra lawan politik serta untuk meningkatkan dukungan dan citra kandidat yang melancarkan aksi provokasi tersebut pada saat menjelang pemilu. Ujaran kebencian memprovokasi yang ditemukan dari hasil analisis ini berkaitan dengan subjek hukum seperti pejabat negara yaitu Bapak Anies Baswedan dan Sandiaga Uno selaku Gubernur dan Wakil Gubernur Dki Jakarta.

Ujaran kebencian kategori menghasut diperoleh sebanyak 1 konteks dari total 20 konteks data dan 12 tuturan $(1,36 \%)$ dari total data keseluruhan yang ditandai dengan unsur-unsur antara lain, (1) sengaja, (2) ditujukan kepada seseorang atau banyak orang, (3) adanya maksud untuk membangkitkan semangat supaya berbuat sesuatu, (4) setelah itu yang terhasut akan melakukan perlawanan atau memberontak. Adapun fungsi dari ujaran kebencian menghasut ini adalah membangkitkan hati orang lain supaya marah dan mau melakukan sesuatu dalam hal ini melawan atau memberontak. Ujaran kebencian menghasut yang ditemukan dari hasil analisis ini berkaitan dengan hal-hal seperti pemilihan Cagub dan Cawagub, Capres dan Cawapres, menuntut polisi, menghukum pelakor, mendemo pendukung Anies Sandi, membubarkan partai PDIP dan menuntut Ibu Sukmawati.

Ujaran kebencian kategori perbuatan tidak menyenangkan diperoleh sebanyak 5 tututan $(0,56 \%)$ dari total data keseluruhan yang ditandai dengan perbuatan tersebut melawan hukum memaksa orang lain supaya (a) melakukan, (b) tidak melakukan, (c) membiarkan sesuatu dengan memakai kekerasan yaitu perbuatan yang menyebabkan cedera, kerusakan fisik atau matinya orang lain serta bersifat memaksa maupun perlakuan yang tidak menyenangkan dengan memakai ancaman kekerasan yaitu menyatakan maksud untuk mencelakakan pihak lain atau memberi peringatan mengenai kemungkinan malapetaka yang bakal terjadi baik terhadap orang itu sendiri maupun orang lain. Ujaran kebencian dalam hal perbuatan yang tidak menyenangkan (mengancam) adalah bentuk ujaran kebencian yang paling sedikit ditemukan dalam hasil penelitian. Ujaran kebencian ini berkaitan dengan ancaman kepada Abu Janda dan Pak Prabowo.

Ujaran kebencian kategori penistaan agama diperoleh sebanyak 5 konteks dari total 20 konteks data keseluruhan yang ditandai dengan unsur-unsur antara lain, (1) adanya hal atau sesuatu yang dikomunikasikan lewat internet, (2) hal atau keadaan tersebut mengenai diri seseorang ataupun kelompok orang, (3) hal 
atau keadaan tersebut dipublikasikan kepada pihak lain, dan (4) publikasi tersebut mengakibatkan pihak yang terkait merasa tersinggung. Adapun kegiatan penistaan yang paling banyak terjadi adalah penistaan agama. Penistaan agama ini ditujukan kepada pelaku ajaran agama, atribut dan simbol-simbol agama. Seperti yang telah dipaparkan pada bab kajian teori mengenai klasifikasi penistaan agama yang tergolong dua jenis yaitu (1) Verbal dengan kata-kata mengolok, sindiran, tuduhan, ejekan dan candaan yang tidak pada tempatnya dan (2) Non verbal dengan tindakan, perilaku atau pandangan bahasa tubuh untuk mengotori ajaran agama masing-masing. Ujaran kebencian penistaan agama yang ditemukan dari hasil analisis ini dilakukan oleh para siswi dari sekolah SMA N 02 TOLI-TOLI, sejumlah lelaki yang tidak diketahui status kebangsaannya, dan puisi dari lbu Sukmawati.

Ujaran kebencian kategori penyebaran berita bohong diperoleh sebanyak 4 konteks dari total 20 konteks data keseluruhan yang ditandai dengan unsurunsur antara lain, (1) adanya hal atau sesuatu yang dikomunikasikan lewat internet, (2) berita yang disebarkan tidak lengkap, tidak jelas dan tidak diketahui kebenarannya, (3) hal atau keadaan tersebut mengenai badan hukum atau badan usaha, (4) hal atau keadaan tersebut dipublikasikan kepada pihak lain, dan (5) publikasi tersebut mengakibatkan kerugian. Adapun bentuk berita bohong (hoax) yang ditemukan pada hasil penelitian berkaitan dengan badan hukum atau badan usaha seperti produk-produk dari perusahaan makanan dan minuman.

Sedangkan tindak tutur ilokusi yang di peroleh dari kolom komentar media sosial facebook (fb) terdapat 882 data. Tindak tutur asertif kategori menyatakan ditemukan sebanyak 44 tuturan atau 4,99 persen dari total keseluruhan yang ditandai dengan piranti linguistik sepertinya, padahal, daripada, mungkin, lebih buruk/baik, jika, kalau, dan sebagainya. Adapun fungsi dari tindak tutur asertif menyatakan adalah tuturan yang disampaikan penutur untuk mengemukakan pendapat atau memberikan informasi kepada mitra tutur yang cenderung bersifat subjektif. Subjektif maksudnya bersifat relatif, informasi tersebut hasil dari menduga-duga atau berdasarkan perasaan atau selera orang.

Tuturan asertif kategori menunjukkan ditemukan sebanyak 39 tuturan atau 4,42 persen dari total keseluruhan yang ditandai dengan piranti linguistik inilah contoh, beginilah jadinya, bukti, ciri-ciri, bentukbentuk, yang dinamakan, disini, dan sebagainya. Adapun fungsi dari tindak tutur asertif menunjukkan adalah untuk memperlihatkan atau menerangkan suatu kebenaran kepada mitra tutur. Tindak tutur menunjukkan ini juga bisa berfungsi untuk memberikan bukti kepada lawan tutur karena tidak memperoleh kepercayaan dari mitra tutur.

Tuturan asertif kategori melaporkan ditemukan sebanyak 83 tuturan atau 9,41 persen dari total keseluruhan yang ditandai dengan piranti linguistik sebentar lagi, ini hasil, itulah, inilah kenyataan, hasil dari, sudah, semua ini, ini bentuk, banyak hal, dan sebagainya. Adapun fungsi dari tindak tutur asertif melaporkan adalah memberikan informasi kepada mitra tutur yang bersifat reportase jadi tuturan ini memberikan laporan terhadap sesuatu hal. Namun tuturan ini tidak semuanya bersifat objektif karena tuturan melaporkan juga dapat bersifat subjektif jika menggunakan anggapan pribadi dan bisa bersifat objektif jika disertai oleh bukti landasan yang kuat.

Tuturan asertif kategori menyebutkan ditemukan sebanyak 28 tuturan atau 3,17 persen dari total keseluruhan yang ditandai dengan piranti linguistik ini, itu, iya, bukan, tidak, ada, si, seperti, banyak, yang, dan 
sebagainya. Adapun fungsi dari tindak tutur asertif menyebutkan adalah untuk memberikan informasi yang singkat namun mitra tutur harus dapat memahami tanpa adanya penjelasan secara menyeluruh. Tindak tutur "menyebutkan" yang dituturkan penutur cenderung bersifat seenaknya atau semaunya. Maksudnya penutur hanya menyebutkan beberapa poin pokok saja, tetapi memaksa lawan tutur untuk menerima dan memahami informasi tersebut.

Tuturan asertif kategori menuntut ditemukan sebanyak 31 tuturan atau 3,51 persen dari total keseluruhan yang ditandai dengan piranti linguistik harus, pokoknya, segera, dan sebagainya. Adapun fungsi dari tindak tutur asertif menuntut adalah tuturan yang disampaikan penutur untuk mengharuskan lawan tuturnya menuruti keinginannya. Tindak tutur "menuntut" yang dituturkan penutur cenderung bersifat memaksa dan harus dituruti lawan tutur atau pihak-pihak tertentu karena tuturan ini biasanya mengandung maksud meminta dengan "keras" (setengah mengharuskan supaya dipenuhi).

Tuturan asertif kategori mengakui ditemukan sebanyak 16 tuturan atau 1,81 persen dari total keseluruhan yang ditandai dengan piranti linguistik memang, lagipula, iya benar/salah, pantas, pasti, mustahil, dan sebagainya. Adapun fungsi dari tindak tutur asertif mengakui adalah tuturan yang disampaikan penutur sebagai bentuk pengakuan atau mengandung maksud menyatakan (mengakui) suatu kebenaran yang bersifat personal (asumsi pribadi) dan kurang akurat karena terdapat asumsi pribadi.

Tuturan asertif kategori memberikan kesaksian ditemukan sebanyak 12 tuturan atau 1,36 persen dari total keseluruhan yang ditandai dengan piranti linguistik tidak mungkin, pernah, tidak begitu, salah, ini fitnah, kenyataannya, emang benar, pengalaman saya, dan sebagainya. Adapun fungsi tindak tutur aserti memberikan kesaksian adalah untuk memberikan keterangan (pernyataan) mengenai suatu kebenaran informasi. Tuturan ini bersifat penegas informasi sehingga menutup peluang lawan tutur bersikap kritis atau membantah.

Tuturan asertif kategori berspekulasi ditemukan sebanyak 35 tuturan atau 3,96 persen dari total keseluruhan yang ditandai dengan piranti linguistik mungkin, jadinya, sepertinya, memangnya, logikanya, kalau, cuma ini, kebanyakan, kayaknya, walaupun, apalagi, pantas saja, janganjangan, dan sebagainya. Adapun fungsi tindak tutur asertif berspekulasi adalah untuk menyampaikan pernyataan (informasi) yang belum diketahui kebenarannya secara pasti dan cenderung tidak sesuai dengan realita (fakta) di lapangan tetapi penutur berspekulasi agar mitra tuturnya menyetujui pernyataan tersebut. Tuturan ini biasanya bersifat tidak sahih, maksudnya informasi yang diberikan tidak benar adanya atau tidak sesuai dengan hukum yang berlaku. Jadi total tindak tutur asertif yang ditemukan sebanyak 288 data dari total 882 tuturan atau sebesar 32,63 persen dari total 100 persen.

Tindak tutur direktif kategori meminta ditemukan sebanyak 25 tuturan atau 2,83 persen dari total keseluruhan yang ditandai dengan piranti linguistik tolong, mohon, bisakah, izin, minta, dan sebagainya. Adapun fungsi dari tindak tutur direktif meminta adalah tuturan yang disampaikan penutur dengan maksud agar mendapatkan sesuatu (tindakan) yang diinginkan dari mitra tutur atau bisa juga meminta mitra tutur menyampaikan pesan kepada orang lain seperti menjadi perantara.

Tuturan direktif kategori bertanya ditemukan sebanyak 30 tuturan atau 3,40 persen dari total keseluruhan yang ditandai dengan piranti linguistik apa, bagaimana, di mana, mengapa, kenapa, ngapain, siapa, 
bisakah, dan sebagainya. Adapun fungsi tindak tutur direktif bertanya adalah mendapatkan informasi yang diinginkan dari mitra tutur dan tuturan ini bisa menghendaki suatu informasi dan tuturan yang menghendaki jawaban yang berupa perbuatan.

Tuturan direktif kategori perintah ditemukan sebanyak 70 tuturan atau 7,93 persen dari total keseluruhan yang ditandai dengan piranti linguistik cari, tangkap, hukum mati, hukum seberat-beratnya, sebarin, suruh, lengserin, musnahin, matiin, liat, tuntut, basmi, dan sebagainya. Adapun fungsi dari tindak tutur direktif perintah adalah tuturan yang disampaikan penutur dengan maksud agar mitra tutur melaksanakan atau melakukan sesuatu. Tindak tutur memerintah ini biasanya bersifat perintah dan berbentuk komando, menggunakan tanda seru dan partikel -lah, menggunakan intonasi bernada tinggi.

Tuturan direktif memesan ditemukan sebanyak 27 tuturan atau 3,06 persen dari total keseluruhan yang ditandai dengan piranti linguistik saran, jangan, harus, ingat, jadilah, usul, dengarlah, jadikan, lebih baik, bagaimana kalau, dan sebagainya. Adapun fungsi dari tindak tutur direktif memesan adalah untuk memberi pesan, petunjuk, saran kepada mitra tutur yang bertujuan untuk membuat perubahan yang lebih baik dari sebelumnya. Tuturan ini bersifat mendorong melakukan sesuatu yang telah dipesankan.

Tuturan direktif menasehati ditemukan sebanyak 24 tuturan atau 2,72 persen dari total keseluruhan yang ditandai dengan piranti linguistik tidak boleh, biarlah, daripada, lebih baik, nasehat, sebaiknya, seharusnya, mendingan, sabar,mestinya, dan sebagainya. Adapun fungsi tindak tutur direktif menasehati adalah agar mitra tutur dapat percaya dan terpengaruh terhadap apa yang disampaikan penutur. Tuturan ini hampir sama seperti memesan, hanya saja pada tuturan menasehati ini sifatnya memberikan anjuran kepada orang lain sedangkan memesan bersifat mendorong melakukan sesuatu yang telah dipesankan.

Tuturan direktif merekomendasikan ditemukan sebanyak 6 tuturan atau 0,69 persen dari total keseluruhan yang ditandai dengan piranti linguistik sebaiknya, rekomendasi, seperti, dan sebagainya. Adapun fungsi tindak tutur direktif merekomendasikan adalah memberikan rekomendasi atau anjuran terhadap sesuatu yang dianggap lebih baik dan benar. Merekomendasikan atau rekomendasi berarti suatu hal yang meminta perhatian bahwa orang yang bersangkutan dapat dipercaya. Jadi, tuturan merekomendasikan dikemukakan untuk memberikan rekomendasi dan memberitahukan kepada satu orang atau lebih dengan sesuatu yang dapat di percaya dan diyakini kebenarannya. Jadi total tindak tutur direktif yang ditemukan sebanyak 182 data dari total 882 tuturan atau sebesar 20,63 persen dari total 100 persen.

Tindak tutur komisif kategori berjanji atau bernazar ditemukan sebanyak 2 tuturan atau 0,22 persen dari total keseluruhan yang ditandai dengan piranti linguistik nazar, janji, akan dan sebagainya. Adapun fungsi tindak tutur direktif berjanji atau bernazar adalah tuturan yang disampaikan penutur dengan maksud akan berbuat atau melakukan sesuatu jika hal yang diinginkan tercapai. Oleh karena itu, tuturan ini bersifat mengikat penutur kepada tindakan yang akan datang karena berbentuk janji baik kepada diri sendiri maupun orang lain.

Tuturan komisif kategori bersumpah ditemukan sebanyak 10 tuturan atau 1,13 persen dari total keseluruhan yang ditandai dengan piranti linguistik sumpah, saya sumpahin, sumpah demi Allah, saya kutuk, dan sebagainya. Adapun fungsi tindak tutur komisif bersumpah adalah mengutuk atau menghukum dalam jangka seumur hidup orang yang bersangkutan. Oleh karena itu, 
tuturan ini bersifat kejam atau tidak menaruh belas kasihan kepada orang yang menerima sumpah tersebut.

Tuturan komisif kategori mengancam ditemukan sebanyak 20 tuturan atau 2,26 persen dari total keseluruhan yang ditandai dengan piranti linguistik jangan, awas, kalau sampai, kalau itu terjadi, akan, dan sebagainya. Adapun fungsi tindak tutur komisif mengancam adalah untuk mencelakakan lawan tutur atau memberikan peringatan tentang petaka yang akan terjadi. Oleh karena itu, tuturan ini bersifat ancaman yang diberikan kepada pihak-pihak tertentu yang penutur benci.

Tuturan komisif kategori menawarkan ditemukan sebanyak 5 tuturan atau 0,57 persen dari total keseluruhan yang ditandai dengan piranti linguistik ada, mending, coba, tips saya, sekalian, bagaimana kalau, dan sebagainya. Adapun fungsi tindak tutur komisif menawarkan adalah untuk mengemukakan pilihan atau memberikan tawaran kepada lawan tutur. Oleh karena itu, tuturan ini bersifat negosiasi atau tawar menawar antara penutur dan mitra tutur yang saling menguntungkan. Namun pada penelitian ini hanya ditemukan tuturan penawaran yang menjebak dan merugikan mitra tuturnya.

Tuturan komisif kategori memanjatkan doa ditemukan sebanyak 29 tuturan atau 3,28 persen dari total keseluruhan yang ditandai dengan piranti linguistik ya Allah, lindungilah, turunkanlah, moga Allah, semoga, mudah-mudahan, saya mendoakan, aamiin ya Allah, dan sebagainya. Adapun fungsi tindak tutur direktif memanjatkan doa adalah untuk menyatakan permohonan (harapan atau permintaan) kepada Tuhan yang ditujukan kepada mitra tutur atau orang-orang tertentu. Oleh karena itu, tuturan ini bersifat sakral dan personal karena menyangkut urusan seseorang (pribadi) dengan Tuhan. Dalam penelitian ini ditemukan doa yang untuk sesuatu hal buruk yang ditujukan untuk orang-orang tertentu.

Tuturan komisif kategori menentang ditemukan sebanyak 8 tuturan atau 0,90 persen dari total keseluruhan yang ditandai dengan piranti linguistik amitamit, najis, tolak, no jokowi, golput, $A B J$, gak mau, mending perang, dan sebagainya. Adapun fungsi tindak tutur direktif menentang adalah untuk menyatakan ketidaksetujuan terhadap suatu keadaan. Oleh karena itu, tuturan ini bersifat penolakan terhadap suatu kebijakan tertentu atau bisa juga menolak keberadaan orang-orang tertentu.

Tuturan komisif kategori menantang ditemukan sebanyak 8 tuturan atau 0,90 persen dari total keseluruhan yang ditandai dengan piranti linguistik ayo siapa takut, berantem sama gue, berani gak, kalau berani, saya tantang, coba, ayo sini, dan sebagainya. Adapun fungsi tindak tutur direktif menantang adalah untuk mengajak melakukan sesuatu perbuatan (berkelahi). Oleh karena itu, tuturan ini cenderung bersifat provokasi atau menghasut yang dapat memancing amarah orang-orang tertentu dan melakukan perlawanan atau memberontak. Jadi total tindak tutur komisif yang ditemukan sebanyak 82 data dari total 882 tuturan atau sebesar 9,26 persen dari total 100 persen.

Tindak tutur ekspresif kategori mengucapkan selamat ditemukan sebanyak 2 tuturan atau 0,22 persen dari total keseluruhan yang ditandai dengan piranti linguistik selamat pada tuturan. Adapun fungsi dari tindak tutur ekspresif mengucapkan selamat adalah untuk memberikan selamat atas sebuah pencapaian. Oleh karena itu, tuturan ini berbentuk ungkapan rasa syukur dan bersifat kejam karena yang disyukuri adalah sebuah malapetaka yang menimpa orangorang yang di benci oleh penutur.

Tuturan ekspresif kategori mengkritik ditemukan sebanyak 112 tuturan atau 
12,69 persen dari total keseluruhan yang ditandai dengan piranti linguistik harusnya sadar, gak santun, kurang didikan, gak mutu, provokator, blagu, sombong, lebay, dan sebagainya. Adapun fungsi tindak tutur ekspresif mengkritik adalah untuk mengomentari atau menanggapi suatu pendapat atau suatu kejadian yang tidak disukai oleh penutur. Oleh karena itu, tuturan ini lebih banyak berbentuk celaan atau kecaman dan menjadi bentuk tuturan yang palimg banyak pada kajian ujaran kebencian di media sosial karena netizen lebih suka mengkritik daripada memuji.

Tuturan ekspresif kategori menyalahkan ditemukan sebanyak 40 tuturan atau 4,53 persen dari total keseluruhan yang ditandai dengan piranti linguistik tidak begitu, kesalahan negeri ini, salah kita, gimana sih, sekolah gak becus, guru gak ngajarin, parah, akibat, orang tua gak tau, dan sebagainya. Adapun fungsi tindak tutur ekspresif menyalahkan adalah ingin melemparkan kesalahan kepada pihakpihak tertentu. Oleh karena itu, tuturan ini biasanya bersifat teguran keras atau tuduhan.

Tuturan ekspresif kategori mengungkapkan perasaan ditemukan sebanyak 10 tuturan atau 1,13 persen dari total keseluruhan yang ditandai dengan piranti linguistik rasanya, miris, sedih, jahat, tersinggung, marah, sakit hati, geram, dan sebagainya. Adapun fungsi dari tindak tutur ekspresif mengungkapkan perasaan adalah untuk mengutarakan isi hati atau memberikan tanggapan dari batin (hati) terhadap suatu keadaan atau kejadian yang dibenci oleh penutur. Oleh karena itu, tuturan ini bersifat personal karena hanya diri penutur sendiri yang bisa merasakannya.

Tuturan ekspresif kategori menghina ditemukan sebanyak 66 tuturan atau 7,48 persen dari total keseluruhan yang ditandai dengan piranti linguistik kaya tai, ini orang tolol, bukan manusia, goblok, bego dipelihara, dasar bencong, lonte, gak punya malu, benar-benar tolol, seperti babi, otak di dengkul, dan sebagainya. Adapun fungsi tuturan ekspresif menghina adalah untuk mempermalukan, menjelekkan nama baik atau menyinggung perasaan mitra tutur. Oleh karena itu, tuturan ini bersifat merendahkan derajat orang-orang yang dihina karena memang tuturan ini ditujukan untuk sesorang atau sesuatu yang dibenci oleh penutur.

Tuturan ekspresif kategori memaki ditemukan sebanyak 81 tuturan atau 9,18 persen dari total keseluruhan yang ditandai dengan piranti linguistik biadab, tolol, bencong, kafir, binatang, lonte, kontol, pepek, anjing, babi, monyet, anak haram, iblis, bajingan, dan sebagainya. Sedangkan penggunaan huruf kapital dan tanda baca seru (!) menunjukkan penggunaan nada tinggi pada tuturan kebencian. Adapun fungsi dari tindak tutur ekspresif kategori memaki adalah untuk menyatakan kemarahan atau meluapkan emosi. Oleh karena itu, tuturan ini bersifat kasar dan tidak terkontrol sehingga penutur tidak memperdulikan perasaan orang yang dimakinya.

Tuturan ekspresif kategori menyindir ditemukan sebanyak 4 tuturan atau 0,45 persen dari total keseluruhan yang ditandai dengan penggunaan piranti linguistik hebat, terima kasih, selamat, jagoan, dan sebagainya. Adapun fungsi tindak tutur ekspresif menyindir adalah untuk memberikan kritikan atau mengejek mitra tutur secara tidak langsung. Oleh karena itu, tuturan ini bersifat celaan yang tersirat atau mengatakan sebuah pujian tetapi bermakna buruk atau kebalikan dari yang diungkapkan.

Tuturan ekspresif kategori membela ditemukan sebanyak 2 tuturan atau 0,22 persen dari total keseluruhan yang ditandai dengan penggunaan piranti linguistik terus kenapa, jangan takut, kamu tidak salah, saya dukung, tetap cantik, lebih cantik, dan 
sebagainya. Adapun fungsi tindak tutur ekspresif membela adalah untuk membantu atau melindungi mitra tutur dari suatu masalah. Oleh karena itu, tuturan ini bersifat memihak kepada orang dibela oleh penutur. Jadi total tindak tutur ekspresif yang ditemukan sebanyak 317 data dari total 882 tuturan atau sebesar 35,9 persen dari total 100 persen.

Tindak tutur deklaratif kategori mengizinkan ditemukan sebanyak 5 tuturan atau 0,57 persen dari total keseluruhan yang ditandai dengan penggunaan piranti linguistik "silahkan". Adapun fungsi tindak tutur deklaratif mengizinkan adalah untuk memperbolehkan melakukan sesuatu hal. Oleh karena itu, tuturan ini biasanya bersifat pernyataan persetujuan dari penutur.

Tuturan deklaratif kategori melarang ditemukan sebanyak 4 tuturan atau 0,45 persen dari total keseluruhan yang ditandai dengan penggunaan piranti linguistik jangan, tidak boleh, tidak usah, dan sebagainya. Adapun fungsi tindak tutur deklaratif melarang adalah untuk memerintahkan supaya tidak melakukan sesuatu atau tidak memperbolehkan berbuat sesuatu. Oleh karena itu, tuturan ini biasanya bersifat pernyataan larangan dari penutur yang merupakan kebalikan dari pernyataan persetujuan.

Tuturan deklaratif kategori menghukum ditemukan sebanyak 1 tuturan atau 0,11 persen dari total keseluruhan yang ditandai dengan penggunaan piranti linguistik hukum, di hukum, hukuman, dan sebagainya. Adapun fungsi tindak tutur deklaratif kategori menghukum adalah untuk menjatuhkan sebuah hukuman kepada mitra tutur. Oleh karena itu, tuturan ini biasanya bersifat menyiksa pihak-pihak yang di hukum.

Tuturan deklaratif kategori mengesahkan ditemukan 4 tuturan atau 0,45 persen dari total keseluruhan yang ditandai dengan penggunaan piranti linguistik halal, lebih pantas, pantas, sebutan, dan sebagainya. Adapun fungsi tindak tutur deklaratif mengesahkan adalah untuk menetapkan atau meresmikan suatu keadaan. Oleh karena itu, tuturan ini biasanya berbentuk pernyataan. Jadi total tindak tutur deklaratif yang ditemukan sebanyak 14 data dari total 882 tuturan atau sebesar 1,58 persen dari total $100 \%$.

\section{PENUTUP}

\section{Kesimpulan}

Berdasarkan data hasil penelitian, dapat disimpulkan bahwa bentuk ujaran kebencian kategori penistaan agama yang paling banyak ditemukan di media sosial facebook (Fb) saat ini yaitu sebesar 25\%, diikuti bentuk ujaran kebencian kategori penyebaran berita bohong (hoax) sebesar $20 \%$, pencemaran nama baik sebesar $15 \%$, memprovokasi sebesar $15 \%$ dan yang paling sedikit ditemui adalah bentuk ujaran kebencian kategori menghasut yaitu sebesar $5 \%$. Sedangkan pada bentuk ujaran kebencian yang paling banyak digunakan oleh para netizen untuk menanggapi informasi di kolom komentar berdasarkan masing-masing konteks tuturan yang bersangkutan adalah bentuk penghinaan sebesar $16,89 \%$, diikuti oleh bentuk ujaran kebencian kategori memprovokasi sebesar $6,12 \%$, lalu menghasut sebesar $1,36 \%$, pencemaran nama baik sebesar 0,90\% dan yang paling sedikit ditemukan adalah bentuk ujaran kebencian kategori perbuatan tidak menyenangkan yaitu sebesar $0,56 \%$.

Sedangkan bentuk tindak tutur ilokusi ekspresif yang paling banyak ditemukan pada tuturan-tuturan netizen di dalam komentar terhadap konteks karena mereka lebih suka menyatakan, mengekspresikan, mengungkapkankan sesuatu yang dirasakan atau memberitahukan sikap psikologis penutur yang mencerminkan kebencian. Tindak tutur ilokusi ekspresif yang paling banyak ditemukan adalah 
bentuk tuturan mengkritik sebesar $12,69 \%$ karena para netizen akan selalu memberikan suatu pendapat atau mencela suatu berita yang tidak sesuai dengan mereka. Diikuti oleh bentuk tindak tutur ilokusi asertif yang terbanyak kedua pada kategori melaporkan sebesar 9,41\%, lalu bentuk tindak tutur ilokusi direktif kategori memberikan perintah lewat tuturan sebesar 7,93\%, kemudian tindak tutur ilokusi komisif kategori memanjatkan doa yang mengandung malapetaka kepada pihak-pihak tertentu sebesar 3,28\% dan yang terakhir adalah bentuk tindak tutur ilokusi deklaratif kategori memberikan izin sebesar $0,57 \%$.

\section{Saran}

Penulis menyadari dalam penelitian mengenai bentuk-bentuk ujaran kebencian dan jenis-jenis tindak tutur ilokusi dalam media sosial facebook (Fb) ini masih kurang sempurna. Lingkup kajian ini membahas bentuk ujaran kebencian secara kebahasaan saja. Begitu juga pada kajian jenis-jenis tindak tutur yang terkandung di dalam tuturan-tuturan netizen di kolom komentar hanya di bahas mengenai jenisjenis tindak tutur ilokusi. Keterbatasan lingkup kajian ini diharapkan dapat membuka peluang bagi peneliti selanjutnya untuk mengembangkan fokus kajiannya terhadap pasal-pasal serta hukum pidana yang mengatur tentang ujaran kebencian tersebut dan mengkaji jenis-jenis tindak tutur ilokusi pada media sosial lain serta mengkaji tuturan para netizen di kolom komentar berdasarkan jenis-jenis tindak tutur perlokusi.

\section{DAFTAR PUSTAKA}

Cummings, L. 2007. Pragmatik Sebuah Perspektif Multidisipliner (1 ed.). (A. S. Ibrahim, Ed., E. setiawati, sunoto, \& dkk, Trans.) Yogyakarta: Pustaka Pelajar.

Effendy, O. U. 2003. IImu, Teori, dan Filsafat Komunikasi . Bandung : Citra Aditya Bakti.

Kapolri. 2015. Penanganan Ujaran Kebencian. Surat Edaran Kapolri Nomor SE/06/X/2015. Jakarta.

Kemendag. 2014. Panduan Optimalisasi Media Sosial Untuk Kementerian Perdagangan RI (1 ed.). (L. H. Hariqo Wibawa Satria, Ed.) Jakarta: Pusat Hubungan Masyarakat.

Mulyana. 2010. Kajian Wacana : Teori, Metode \& Prinsip-prinsip Analisis Wacana. Yogyakarta: Tiara Wacana.

Robbins, S. P., \& Judge, T. A. 2014. Perilaku Organisasi (16 ed.). Jakarta: Salemba Empat.

Soesilo, R. 1991. Kitab Undang-undang Hukum Pidana. Bogor: Politeia.

Subarianto, J. 1999. Kebakuan dan Ketidakbakuan Kalimat dalam Bahasa Indonesia. Yogyakarta: Mitra Gama Widya. 